University of Wollongong

Research Online

Faculty of Engineering and Information

Faculty of Engineering and Information

Sciences - Papers: Part A

Sciences

$1-1-2012$

Indian Millennials: Are microchip implants a more secure technology for identification and access control?

Christine Perakslis

Johnson And Wales University

Katina Michael

University of Wollongong, katina@uow.edu.au

Follow this and additional works at: https://ro.uow.edu.au/eispapers

Part of the Engineering Commons, and the Science and Technology Studies Commons

Research Online is the open access institutional repository for the University of Wollongong. For further information contact the UOW Library: research-pubs@uow.edu.au 


\title{
Indian Millennials: Are microchip implants a more secure technology for identification and access control?
}

\begin{abstract}
This mixed methods study with a sequential explanatory strategy explored qualitatively the statistically significant quantitative findings relative to Indian respondents' perceptions about RFID (radio frequency identification) transponders implanted into the human body. In the first analysis phase of the study, there was a significant chi-square analysis reported $(\chi 2=56.64, \mathrm{df}=3, \mathrm{p}=.000)$ relative to the perception of small business owners $(\mathrm{N}=453)$ that implanted chips are a more secure form of identification and/or access control in organizations and the respondents' country of residence. Countries under study included Australia, India, the UK and US. The country contributing most to this significant relationship was India. Additionally, frequency data comparing the relationship of the respondents' generation and perceptions of implants as a more secure technology (yes-no) was examined. The significant chi-square $(\chi 2=29.11, d f=2, p=.000)$ analysis indicated that there was a very significant relationship between the respondents' opinions and such generations as Baby Boomers (those born 1946-1965), Generation X (those born 1966-1980) and Generation Y (those born 1981-2000). The second analysis phase of the study explored qualitative data gleaned from open-ended questions asking Indian Millennials (born 1981-2000) about their feelings about being implanted with a chip. Over one third of the world's population is considered part of the Millennial generation. Of India's 1.2 billion people, approximately half are under the age of 25; that is, over 250 million are categorized as Millennials. Based on the quantitative and qualitative findings, researchers in this study concluded that three factors affect perceptions of RFID implants. One key factor is that Indian Millennials appear to describe more feelings of positivity and neutrality when compared with the two prior generations. (C) 2012 IEEE.
\end{abstract}

\section{Keywords}

more, secure, technology, identification, access, indian, control, millennials, microchip, implants

\author{
Disciplines \\ Engineering | Science and Technology Studies
}

\section{Publication Details}

Perakslis, C. \& Michael, K. (2012). Indian Millennials: Are microchip implants a more secure technology for identification and access control?. In M. Arnold, M. R. Gibbs, G. Adamson \& P. Hall (Eds.), Proceedings of the 2012 IEEE Conference on Technology and Society in Asia, T and SA 2012 (pp. 1-9). NY, USA: IEEE. 


\section{Indian Millennials: Are microchip implants a more secure technology for identification and access control?}

\author{
Christine Perakslis, Ed.D. \\ Alan Shawn Feinstein Graduate School \\ Johnson \& Wales University \\ Providence, Rhode Island, USA \\ cperakslis@jwu.edu
}

\author{
Katina Michael, Ph.D. \\ School of Information Systems and Technology \\ University of Wollongong \\ NSW, Australia \\ katina@uow.edu.au
}

\begin{abstract}
This mixed methods study with a sequential explanatory strategy explored qualitatively the statistically significant quantitative findings relative to Indian respondents' perceptions about RFID (radio frequency identification) transponders implanted into the human body. In the first analysis phase of the study, there was a significant chi-square analysis reported $\left(\chi^{2}=56.64, d f=3, p=.000\right)$ relative to the perception of small business owners $(N=453)$ that implanted chips are a more secure form of identification and/or access control in organizations and the respondents' country of residence. Countries under study included Australia, India, the UK and US. The country contributing most to this significant relationship was India. Additionally, frequency data comparing the relationship of the respondents' generation and perceptions of implants as a more secure technology (yes - no) was examined. The significant chi-square $\left(\chi^{2}=29.11, d f=2, p=.000\right)$ analysis indicated that there was a very significant relationship between the respondents' opinions and such generations as Baby Boomers (those born 1946 - 1965), Generation $X$ (those born 1966-1980) and Generation Y (those born 1981-2000). The second analysis phase of the study explored qualitative data gleaned from openended questions asking Indian Millennials (born 1981-2000) about their feelings about being implanted with a chip. Over one third of the world's population is considered part of the Millennial generation. Of India's 1.2 billion people, approximately half are under the age of 25; that is, over 250 million are categorized as Millennials. Based on the quantitative and qualitative findings, researchers in this study concluded that three factors affect perceptions of RFID implants. One key factor is that Indian Millennials appear to describe more feelings of positivity and neutrality when compared with the two prior generations.
\end{abstract}

Keywords-RFID; radio frequency identification; microchips; surgically implanted chips; India; surveillance; access control; employee identification

\section{INTRODUCTION}

The purpose of this study was to explore and interpret qualitatively the statistically significant quantitative findings relative to Indian respondents' perceptions about RFID (radio frequency identification) transponders implanted into the human body for identification and access control purposes in organizations. RFID implants are defined as an omnipresent electronic surveillance, which utilize technology that makes it possible to implant devices into the human body to track the who, what, where, when, and how of human life [1]. The tiny RFID chip which can be implanted in the body is smaller than the size of a grain of rice. In the first phase of analysis, there was a very significant chi-square analysis $\left(\chi^{2}=56.64, d f=3, p\right.$ $=.000)$ reported relative to the perception that surgically implanted chips are a more secure form of identification and/or access control and the respondents' country of residence. In the first phase, participants included small business owners $(N=$ 453) within four countries including the UK $(n=111)$, the USA $(n=117)$, Australia $(n=114)$, and India $(n=111)$. The country contributing most to this significant relationship was India. In rank order, the countries contributing to this significant relationship were India, the UK, and the USA; no such differences in opinion were found for respondents from Australia. The second phase of the study explored qualitative data relative to surgically implanted chips reported by a subsection of the aforementioned small business owners; data reported by those Indian small business owners categorized as Millennials $(N=62)$ was analyzed, as well as data reported by Indian students $(N=25)$ categorized as Millennials (born 19802000) and currently enrolled in a college or university.

The methodology of this study took into account an initial analysis of quantitative findings of a survey exploring if small business owners perceived RFID chip implants in humans as a more secure technology for employee identification. The researchers intended to investigate if country of residence and/or generation (i.e. a cohort of individuals who were born in the same date range and share similar cultural experience) may affect perceptions of RFID implants in humans. Quantitative analysis revealed more Indian small business owners than expected perceived chip implants as a more secure technology. Indian participants, therefore, became an increased focus to further investigate why this segment of the participants reported more openness to implants than expected. Additional quantitative analysis exploring perceptions about this emerging technology by generation revealed more Millennials than expected perceived implants as more secure technology and conversely, less than expected Baby Boomers. Millennials, therefore, became a increased focus to further investigate why this segment of the participants reported more openness to 
implants than expected. Therefore, to bring meaning to the quantitative findings and further explore openness, the researchers then began qualitative exploration of data from the same survey to investigate how Indian participants, and Millennials, in general, answered when asked how he/she "personally feel(s) about being implanted for ease of identification with your own organization" when contrasted against the comments of non-Indian and/or non-Millennials. Then, to further expand upon qualitative findings about openness to implants from the aforementioned survey, the researchers are in the process of conducting subsequent research of Indian Millennials who are enrolled in graduate studies, but not necessarily small business owners. These qualitative themes were taken into account for the conclusions as reported in this paper.

The authors present a brief review of the literature, key findings from the sequential study, and a discussion on possible implications of the findings. Professionals working in the field of emerging technologies could use these findings to better understand how such demographics as country of residence, as well as such psychographics as generational factors, may affect perceptions of chip implants for identification and access control purposes in organizations.

\section{REVIEW OF LITERATURE}

\section{A. Implants \& Social Acceptance}

RFID implants, also known as Uberveillance, are defined as an omnipresent electronic surveillance, which utilize technology that makes it possible to implant devices into the human body to track the who, what, where, when, and how of human life [1]. In 2004, the FDA (Food \& Drug Administration) of the United States approved an implantable chip for use in humans in the U.S. The tiny RFID chip, which can be implanted in the body, is smaller than the size of a grain of rice. The implanted chip is being marketed as a potential method to detect and treat diseases, as well as a potential lifesaving device. If a person was brought to an emergency room unconscious, a scanner in the hospital doorway could read the person's unique ID on the implanted chip. The ID would then be used to unlock the medical records of the patient from a database. Authorized health professionals would then have access to all pertinent medical information of that individual (i.e. medical history, previous surgeries, allergies, heart condition, blood type, diabetes, etc.) to care for the patient aptly.

Recent technological developments are reaching new levels with the integration of silicon and biology; implanted devices can now interact directly with the brain [2]. Implantable devices for medical purposes are often believed highly beneficial to restore functions that were lost. Such current medical implants include cardiovascular pacers, cochlear and brainstem implants for patients with hearing disorders, implantable drug delivery pumps, implantable neurostimulation devices for such patients as those with urinary incontinence, chronic pain, or epilepsy, deep brain stimulation for patients with Parkinson's, and artificial chip-controlled legs [3].
Social concerns plague this technology [4]. In the United States, many states are crafting legislation to balance the potential benefits of RFID technology with the disadvantages associated with privacy and security concerns. California, Georgia, Missouri, North Dakota, and Wisconsin are among states in the U.S. which have passed legislation to prohibit forced implantation of RFID in humans [5]. The "Microchip Consent Act of 2010", which became effective on July 1, 2010 in the state of Georgia, not only stated that no person shall be required to be implanted with a microchip (regardless of a state of emergency), but also that voluntary implantation of any microchip may only be performed by a physician under the authority of the Georgia Composite Medical Board [6].

Through the work of Rodata and Capurro (2005), the European Group on Ethics in Science and New Technologies to the European Commission, which examines ethical questions arising from science and new technologies, issued an opinion in 2005, primarily to raise awareness and dialogue concerning the dilemmas created by both medical and nonmedical implants in humans which affect the intimate relation between bodily and psychic functions basic to our personal identity. The opinion stated that implants (referred to as ICT implants or Information \& Communications Technology implants), should not be used to manipulate mental functions or to change a personal identity. Additionally, the opinion stated that principles of data protection must be applied to protect personal data embedded in implants. The implants were identified in the opinion as a threat to human dignity when used for surveillance purposes, although the opinion stated that this might be justifiable for security and/or safety reasons [7].

Researchers continue to investigate social acceptance of the implantation of this technology into human bodies. In 2006, Perakslis and Wolk reported higher levels of acceptance of the implantation of a chip within their bodies, when college students perceived benefits from this technology [8]. A 2010 survey by BITKOM, a German information technology industry lobby group, reported $23 \%$ of 1000 respondents would be prepared to have a chip inserted under their skin for certain benefits; $72 \%$ of respondents, however, reported they would not allow implantation of a chip under any circumstances. Sixteen percent $(16 \%)$ of respondents reported they would accept an implant to allow emergency services to rescue them more quickly in the event of a fire or accident [9].

\section{B. Shifts with Millennials: From Unwillingness toward Neutrality to Implant}

Utilizing questions posed by researchers in 2005 to college students attending both private and public institutions of higher education, researchers once again investigated levels of willingness to implant RFID chips to understand if there were shifts in levels of willingness of college students to implant RFID chips for various reasons [8] [10]In both studies, students were asked: "How willing would you be to implant an RFID chip in your body as a method... (to reduce identity theft, as a potential lifesaving device, to increase national security)?" A 5point Likert-type scale was utilized varying from "Strongly Unwilling" to "Strongly Willing". Comparisons of the 2005 results of the study to the results of the 2010 research revealed shifts from unwillingness toward either neutrality or 
willingness to implant a chip in the human body to reduce identity theft, as a potential lifesaving device, and to increase national security. Levels of unwillingness decreased for all aforementioned areas as follows [10].

Between 2005 and 2010, the unwillingness ("Strongly unwilling" and "Somewhat unwilling") of college students to implant an RFID chip into their bodies decreased by $22.4 \%$ (from 55\% strongly \& somewhat unwilling in 2005 to $32.6 \%$ strongly and somewhat unwilling in 2010) when considering RFID implants as method to reduce identity theft, decreased by $19.9 \%$ when considering RFID implants as a potential lifesaving device (from $42 \%$ strongly \& somewhat unwilling in 2005 to $22.1 \%$ in 2010), and decreased by $16.3 \%$ (from $50 \%$ strongly and somewhat unwilling in 2005 to $33.7 \%$ in 2010) when considering RFID implants to increase national security [10].

\section{Shifts with Millennials: More Willingness to Implant}

Between 2005 and 2010, researchers reported that levels of willingness increased for all areas under study. The willingness ("strongly willing" and "somewhat willing") of college students to implant an RFID chip into their bodies increased by 9.2\% when considering RFID implants as method to reduce identity theft, increased $24.4 \%$ when considering RFID implants as a potential lifesaving device, and increased $10.1 \%$ when considering RFID implants to increase national security. Researchers (Perakslis, 2010) reported the most dramatic shift in willingness with college students appeared to be relative to implanting RFID chips for use as a potential lifesaving device. The willingness of college students in 2010 increased by $24.4 \%$, shifting from less unwillingness (-19.9\%), and less neutrality as well $(-4.5 \%)$ [8] [9].

\section{Shifts with Millennials: More Neutral/No Opinion}

In the same study (Perakslis, 2010), there was a 13.2\% increase of participants categorized as Millennials reporting "neutral/no opinion" about willingness to implant a chip to reduce identity theft, and a $6.2 \%$ increase relative to willingness to implant a chip to increase national security. Conversely, when asked about willingness to implant a chip as a potential lifesaving device, $6.2 \%$ fewer participants reported "neutral/no opinion" in 2010 when compared to 2005 [8] [10].

\section{E. Millennials}

Millennials, are also known as Generation Y, Gen-Yers, Echo Boomers, Generation Next, or the Net Generation [14]. This segment of the population is defined by the U.S. Bureau of Labor Statistics as those born between 1981 and 2000 [11], and they are the cohort following Generation X (born between 1966 - 1980), and Baby Boomers (born between 1946 - 1964) [11]. Over one third of the population of the world is categorized as part of the Millennial generation; there are more Millennials in India than the total populations of Germany, Spain, France, and the U.K. combined [12]. This generation is immersed in technology; $74 \%$ of Millennials polled, in a multicountry internet study $(\mathrm{N}=2500)$ reported they are skilled to "handle whatever technology encountered" [12]. Technology need not be for utilitarian purposes; these individuals view technology as central to their way of life $(32 \%)$ and use technology to express themselves creatively (36\%). One of the most significant aspect of the life of a Millennial is to be diverse and accepting [12]. Speed and access are keys to engage these individuals; they are accustomed to having gadgets that allow them to be the always-connected generation [13]. Researchers report that $74 \%$ of those polled in this generation, reported it is important for them to be perceived as "someone who is accepting of people from other cultures". Indian Millenials are believed to share similar traits to their counterparts across the world however, when compared with western peers Indian Millennials identify more strongly with their parents, traditions, and culture [12]. Howe and Strauss (2000) purported that this generation can be defined by seven core traits and they are: special, sheltered, confident, teamoriented, conventional, pressured, and achieving. The life mission of this generation is reported to be to build up new institutions rather than tear down old institutions that do not work [14].

\section{F. Shifts in India}

Due to heightened security threats, there is a surge in demand for security in India [15] [16]. A progression of masscasualty assaults that have been carried out by extremist Pakistani nationals against hotels and government buildings in India has brought more awareness to the potential threats against less secure establishments [16]. The government is working to institute security measures at the individual level with a form of national ID cards that will house key biometric data of the individual [17]. In the local and regional settings, technological infrastructure is developing rapidly in metro and non-metro areas because of the increase of MNCs (multinational corporations) now locating in India. Although the neighborhood chowkiddaaar (human watchman/guard) was previously a more popular security measure for localized security, advances in, and reliability and availability of, security technology is believed to be affecting the adoption of electronic access security as a replacement to the more traditional security measures [15] [16].

\section{METHODOLOGY}

This study used a mixed-methods design with a sequential explanatory strategy. The initial quantitative phase informed the qualitative phase; qualitative research was used to examine surprising quantitative results in more detail [18]. The first phase included participants who are small business owners $(N$ = 453) within four countries including the UK, the USA, Australia, and India. Chi-square analysis was conducted in this study to examine if there was a relationship between the perception that surgically implanted chips are a more secure technology, and the respondents' country of residence. Additionally, Chi-square analysis was conducted to examine if there was a significant relationship between the respondents' generations. Generations were defined as Millenials (19812000), Generation X (1965-1980) and Baby Boomers (19461964).

The second phase included analysis of qualitative data obtained through the aforementioned survey asking participants "How would you personally feel about being implanted for ease of identification with your own organization?" as well as a 
subsequent survey administered to Indian Millennial students who are enrolled in gradaute school, but not necessarily small business owners. The collection and analysis of data gleaned from the open-ended questions administered electronic surveys explored the perspective of Indians as well as Millennials relative to surgically implantable RFID transponders when compared to those participants who were non-Indian and/or non-Millennials. Participants included both Indian small business owners categorized as Millennials $(N=62)$ and purposefully selected Indian students who were also Millennials and currently enrolled in a college or university ( $N$ $=25)$.

\section{FINDINGS}

In the first phase of the study, the frequency data that compared the relationship of the country in which the respondent lives was examined as shown in Table 1. The country or residence was explored relative to perceptions of surgically implanted transponders beneath the skin of an employee as a more secure technology for employee identification (yes - no). The significant chi-square $\left(\chi^{2}=56.64\right.$, $d f=3, p=.000$ ) indicated that there was a relationship between the respondents' opinions and their country. Using the rule of identifying adjusted residuals greater than 2.0 [19], examination of the adjusted residuals indicated that the relationship was mostly created when more residents from India responded "yes" than expected (46 vs. 19.8; adjusted residual $=7.5$ ). In addition, fewer residents from the UK responded "yes" than expected (9 vs. 19.8), and fewer residents from the USA responded "yes" than expected (11 vs. 20.9). Thus, the researchers concluded that there was a relationship between the perception that surgically implanted chips are a more secure technology for instituting employee identification and the respondents' country. In rank order, the countries contributing to this significant relationship were India, the UK and the USA; no such differences in opinion were found for respondents from Australia.

\section{TABLE 1}

\begin{tabular}{|c|c|c|c|c|c|c|}
\hline \multirow{2}{*}{\multicolumn{3}{|c|}{$\begin{array}{l}\text { Country of Residence and Surgically Implanted Transponders as a } \\
\text { More Secure Technology for Employee Identification }\end{array}$}} & \multicolumn{4}{|c|}{ Comtry in which the respondent lives } \\
\hline & & & UK & USA & Australia & India \\
\hline \multirow{8}{*}{$\begin{array}{l}\text { Q55 - Do you think } \\
\text { radiofrequency identification } \\
\text { (RID) transponders } \\
\text { surgically inplanted beneath } \\
\text { the skin of an employee is a } \\
\text { more secure technology for } \\
\text { intitutung employee } \\
\text { identification in your } \\
\text { organisation? }\end{array}$} & \multirow[t]{4}{*}{ Yes } & Count & 9 & 11 & 15 & 46 \\
\hline & & Expected Comut & 19.8 & 209 & 20.4 & 19.8 \\
\hline & & \% within Q55 & $11.1 \%$ & $13.6 \%$ & $18.5 \%$ & $36.8 \%$ \\
\hline & & Adjusted Residual & .3 .1 & .2 .8 & .1 .5 & 7.5 \\
\hline & \multirow[t]{4}{*}{ No } & Count & 102 & 106 & 99 & 65 \\
\hline & & Expected Count & 91.2 & 96.1 & 93.6 & 91.2 \\
\hline & & $\%$ within 055 & $27.4 \%$ & $28.5 \%$ & $26.6 \%$ & $17.5 \%$ \\
\hline & & Adjusted Residual & 3.1 & 28 & 1.5 & .7 .5 \\
\hline
\end{tabular}

Additionally in the first phase of the study, the frequency data that compared the relationship of the generation to which the respondent belongs and support of surgically implanted transponders beneath the skin of an employee as a more secure technology for employee identification (yes - no) was examined as shown in Table 2 . The significant chi-square $\left(\chi^{2}=\right.$ 29.11, $d f=2, p=.000$ ) indicated that there was a relationship between the respondents' opinions and the generation of Baby Boomers, Generation X, or Generation Y, as defined by the Bureau of Labor Statistics. Using the rule of identifying adjusted residuals greater than 2.0 [19], examination of the adjusted residuals indicated that the relationship was mostly created when fewer participants categorized as Baby Boomers responded "yes" than expected (16 vs. 35 ; adjusted residual = 4.7). In addition, more participants categorized as Millennials responded "yes" than expected (31 vs. 16.5). Thus, the researchers concluded that there was a relationship between the perception that surgically implanted chips are a more secure technology for instituting employee identification and the respondents' generation. In rank order, the generations contributing to this significant relationship were Baby Boomers, and then the Millennials; no such differences in opinion were found for respondents who are categorized as Generation X.

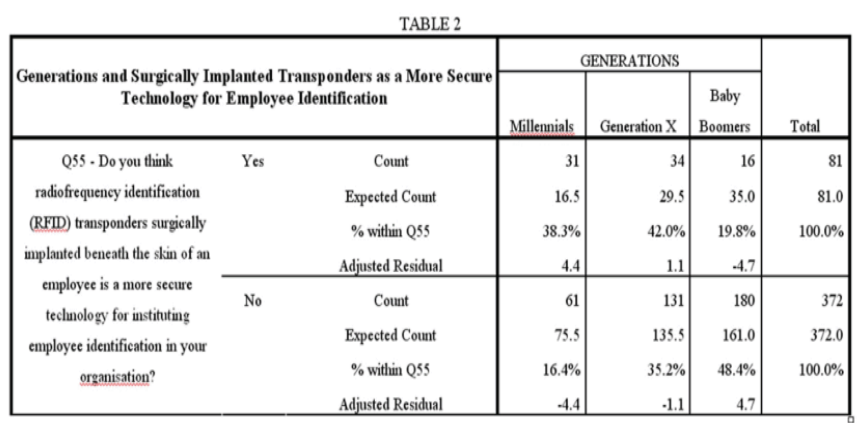

In the second phase of the study, data from two surveys were gleaned. Data from the first questionnaire that was administered to small business owners was collected concurrently during the quantitative phase. A second questionnaire with open-ended questions was then subsequently administered to Indian Millennial students enrolled in colleges or universities. These findings allowed the researchers to better understand the meaning attached by Indian Millennials when they considered being chipped personally. Participants were asked "How would you personally feel about being implanted for ease of identification with your own organization?" Data was analyzed and four major themes emerged: 1) positive perceptions of being chipped relative to innovation, 2) positive perceptions of being chipped corresponding to security, 3) ambivalence when considering chip implants; and 4) openness to being chipped.

Compared to qualitative data from other generations, few of the Indian Millennial participants expressed negative comments and those participants who did express unwillingness did so in a mild manner. These comments included, "It will be easy, but I don't prefer (RFID implants)" and "I won't agree to it".

When considering the theme of positive perceptions relating to innovation, one Indian Millennial participant stated, "It is good to use a new technology" and another stated, "It is a new concept, but I like the concept". One participant succinctly stated implants are a "good innovation."

When considering the theme of RFID implants perceived as positive and corresponding to security, participants' comments included, "It is very secure and is very useful in our organization" and "(I would) feel secure". Some participants attached the feelings of security to specific aspects of an organization with comments such as “...it would make me feel 
secure about my work and position" and "This creates security regards [sic] to business".

When considering the theme of ambivalence, Indian Millennial participants expressed a concurrent mix of positive and negative sentiments with such comments as "It is very useful, but at the same time it is also risky" and "It is good, but the need for such high security measures is something unnecessary..." Neutrality was evident when Millennials reported, "I don't know (how I feel about being chipped)." And such comments as: "(I) don't care" or "I do not feel anything (for this technology)..."

When considering the theme of openness of Indian Millennials to personally being chipped, Millennials said, "Not yet, (will) think about it" and "I'm open to the idea of getting an implant." One respondent wrote, "never opted for the idea, but surely would like to try it." Additionally, another participant shared "I don't think I have a problem with implantation" and another succinctly noted "Cool".

\section{DISCUSSION}

More than expected, Indian participants overall, perceived implants as a more secure technology for identification/access control in this study. Also, more than expected, participants categorized as part of the Millennial generation (born 19812000) overall, perceived implants as a more secure technology for identification/access control; conversely, fewer Baby Boomers than expected perceived implants as a more secure technology for identification/access control. This created the impetus for the researchers to explore how Indian participants who are categorized as Millennials would describe their feelings when considering getting an RFID implant.

When using data from open ended questions to bring meaning to the quantitative findings, Indian Millennials frequently expressed and/or attached positive or neutral meanings when describing how they feel about this emerging technology. This is in line with previous research (Perakslis, 2010) that investigated changes between 2005 and 2010 in levels of willingness to adopt an implant. The longitudinal research showed that in 2010, Millennials reported neutrality of opinion ("no opinion/neutral") $13.2 \%$ more (from $11 \%$ of participants reporting neutral opinions in 2005 to $24.2 \%$ in 2010) when asked about willingness to implant a chip to reduce identity theft and $6.2 \%$ more (from $18 \%$ of participants reporting neutral opinions in 2005 to $24.2 \%$ in 2010) when asked about willingness to implant a chip to increase national security when compared to findings in 2005. Surprisingly, these participants were the only generation to convey noteworthy expressions of neutrality when compared with participants belonging to Generation X and/or Baby Boomers.

Thus, the researchers conclude three factors may affect perceptions about RFID implants as a more secure technology for identification and access control purposes. These are: 1) one's country of residence may inform perceptions, 2) generational factors may affect one's perception; and 3) participants whose country of residence was India and who are also categorized as Millennials describe more positive feelings generally, less negative feelings overall, and more neutral feelings about this technology when compared with the two prior generations.

\section{CONCLUSION}

In conclusion, the researchers purport that such demographics as country of residence, as well as such psychographics as generational factors appear to affect perceptions of chip implants for identification and access control purposes in organizations. One limitation to this study could have been the psychographics of the participants; small business owners are often believed to be risk-takers and may exhibit more openness [20]. A second limitation to this study may be related to the timing of the data collection; there was a heightened awareness in India to security threats. A third limitation to this study may be related to religious beliefs; the researchers did not control for religious beliefs of participants in this study.

\section{ACKNOWLEDGMENT}

The authors acknowledge the financial support from the Institute for Innovation in Business and Social Research for the electronic survey that was deployed to four countries. In addition, we recognize the contributions of Dr. Felice Billups, Dr. Robert Gable, both of Johnson \& Wales University, Dr. Michael Michael, formerly of the University of Wollongong, and the late Dr. Robert Wolk, formerly of Bridgewater State University, who was a long-time IEEE_SSIT member and coauthored one of the first published surveys on microchip implants in IEEE Technology and Society Magazine in 2006. This study is done, in large part, to fulfill Dr. Wolk's wishes to continue to investigate the social implications of such emerging technologies.

\section{REFERENCES}

[1] M.G. Michael and K. Michael. "Towards a State of Uberveillance" IEEE Technology and Society Magazine 29.2 (2010): 9-16.

[2] Gasson, M. (2008). ICT implants: the invasive future of identity? [Electronic version]. Advances in Information and Communication Technology, 262(2), 287-295.

[3] Capurro, R. (2010, June). Ethical aspects of ICT implants in the human body. Paper presented at the meeting of The IEEE Symposium on Technology and Society (ISTAS10), New South Wales, Australia.

[4] Masters, A., \& Michaels, K. (2007). Lend me your arms: The use and implications of humancentric RFID [Electronic version]. Electronic Commerce and Applications, 6(1), 29-39.

[5] Angelo Friggieri, K. Michael, and M.G. Michael. "The Legal Ramifications of Microchipping People in the United States of Americaa State Legislative Comparison" 2009 IEEE International Symposium on Technology and Society (ISTAS '09). Phoenix, Arizona: IEEE Computer Society, 2009. 1-8.

[6] Georgia General Assembly (2010). Senate Bill 235. Retrieved January 12, 2011, from http://www1.legis.ga.gov/legis/2009_10/versions/sb235_ As_passed_Senate_5.htm.

[7] Rodota, S. \& Capurro, R. (2005). Opinion $n^{0} 20-16 / 03 / 02005$ : Ethical aspects of ICT Implants in the human body. Retrieved December 12 , 2010, from http://ec.europa.eu/european_group_ethics/docs/ avis20_en.pdf

[8] Perakslis, C., \& Wolk, R. (2006). Social acceptance of RFID as a biometric security method. IEEE Symposium on Technology and Society Magazine, 25(3), 34-42. 
[9] Donoghue, A. (2010). CeBit: Quarter of Germans Happy to Have Chip Implants. Retrieved June 1, 2012 from https://www.techweekeurope.co.uk/news/cebit-quarter-of-germanshappy-to-have-chip-implants-5590

[10] Perakslis, C. (2013). Consumer Willingness to Adopt RFID Implants: Do Personality Factors Play a Role in the Acceptance of Uberveillance? In "Uberveillance and the Social Implications of Microchip Implants" Hershey, PA: IGI Global, paper accepted.

[11] U.S. Bureau of Labor Statistics (2011). Generations in the Workplace in the United States \& Canada. Retrieved May 1, 2012, from http://www.catalyst.org/publication/434/generations-in-the-workplacein-the-united-states-canada

[12] The Futures Company (2009). Millenials Ahead. Retrieved May 1, 2012, from http://www.lifebenefits.com/lb/pdfs/Millennials_Ahead_Report.pdf

[13] Pew Research Center for the People and the Press (2010). Millenials: A Portrait of the Generation Next. http://www.pewsocialtrends.org/files/ 2010/10/millennials-confident-connected-open-to-change.pdf
[14] Howe N. \& Strauss, W. (2000). Millennials Rising. New York: Vintage Books.

[15] Das S. (2009). Surveillance: Big Brothers Watching. Retrieved May 1, 2012, from http://dqindia.ciol.commakesections.asp/09042401.asp

[16] Krepon M.\& Cohn, N. (2011). Crises in South Asia: Trends and Potential Consequences. Retrieved May 1, 2012 from http://www.stimson.org/books-reports/crises-in-south-asia-trends-andconsequences/

[17] Romero, J. (2011). Fast Fast Start for World's Biggest Biometrics ID Project. Retrieved August 1, 2012 from

http://spectrum.ieee.org/computing/it/fast-start-for-worlds-biggestbiometrics-id-project/

[18] Creswell , J. (2003). Research design. (2nd ed.). Thousand Oaks, CA: Sage.

[19] S Haberman, Shelby J. 1973. "The Analysis of Residualsin CrossClassified Tables." Biometrics

29:205-20.

[20] Praendex Corporation. (1999). Predictive Index Reference Manual. WellesleyHills, MA: Praendex. 
TABLE 1

\begin{tabular}{|c|c|c|c|c|c|c|}
\hline \multirow{2}{*}{\multicolumn{3}{|c|}{$\begin{array}{l}\text { Country of Residence and Surgically Implanted Transponders as a } \\
\text { More Secure Technology for Employee Identification }\end{array}$}} & \multicolumn{4}{|c|}{ Country in which the respondent lives } \\
\hline & & & $\mathrm{UK}$ & USA & Australia & India \\
\hline \multirow{8}{*}{$\begin{array}{c}\text { Q55 - Do you think } \\
\text { radiofrequency identification } \\
\text { (RFID) transponders } \\
\text { surgically implanted beneath } \\
\text { the skin of an employee is a } \\
\text { more secure technology for } \\
\text { instituting employee } \\
\text { identification in your } \\
\text { organisation? }\end{array}$} & \multirow[t]{4}{*}{ Yes } & Count & 9 & 11 & 15 & $\overline{46}$ \\
\hline & & Expected Count & 19.8 & 20.9 & 20.4 & 19.8 \\
\hline & & $\%$ within Q55 & $11.1 \%$ & $13.6 \%$ & $18.5 \%$ & $56.8 \%$ \\
\hline & & Adjusted Residual & -3.1 & -2.8 & -1.5 & 7.5 \\
\hline & \multirow[t]{4}{*}{ No } & Count & 102 & 106 & 99 & 65 \\
\hline & & Expected Count & 91.2 & 96.1 & 93.6 & 91.2 \\
\hline & & \% within Q55 & $27.4 \%$ & $28.5 \%$ & $26.6 \%$ & $17.5 \%$ \\
\hline & & Adjusted Residual & 3.1 & 2.8 & 1.5 & -7.5 \\
\hline
\end{tabular}

TABLE 2

\begin{tabular}{|c|c|c|c|c|c|c|}
\hline \multirow{2}{*}{\multicolumn{3}{|c|}{$\begin{array}{c}\text { Generations and Surgically Implanted Transponders as a More Secure } \\
\text { Technology for Employee Identification }\end{array}$}} & \multicolumn{3}{|c|}{ GENERATIONS } & \multirow{2}{*}{ Total } \\
\hline & & & \multirow{2}{*}{$\frac{\text { Millennials }}{31}$} & \multirow{2}{*}{$\frac{\text { Generation X }}{34}$} & $\begin{array}{c}\text { Baby } \\
\text { Boomers }\end{array}$ & \\
\hline \multirow{8}{*}{$\begin{array}{l}\text { Q55 - Do you think } \\
\text { radiofrequency identification } \\
\text { (RFID) transponders surgically } \\
\text { implanted beneath the skin of an } \\
\text { employee is a more secure } \\
\text { technology for instituting } \\
\text { employee identification in your } \\
\text { organisation? }\end{array}$} & Yes & Count & & & 16 & 81 \\
\hline & & Expected Count & 16.5 & 29.5 & 35.0 & 81.0 \\
\hline & & \% within Q55 & $38.3 \%$ & $42.0 \%$ & $19.8 \%$ & $100.0 \%$ \\
\hline & & Adjusted Residual & 4.4 & 1.1 & -4.7 & \\
\hline & No & Count & 61 & 131 & 180 & 372 \\
\hline & & Expected Count & 75.5 & 135.5 & 161.0 & 372.0 \\
\hline & & $\%$ within Q55 & $16.4 \%$ & $35.2 \%$ & $48.4 \%$ & $100.0 \%$ \\
\hline & & Adjusted Residual & -4.4 & -1.1 & 4.7 & \\
\hline
\end{tabular}

Table 1

\begin{tabular}{|c|c|c|c|c|c|c|}
\hline & & & \multicolumn{4}{|c|}{ Country in which the respondent lives } \\
\hline & & & UK & USA & Australia & India \\
\hline \multirow{8}{*}{$\begin{array}{l}\text { Q55 - Do you think } \\
\text { radiofrequency } \\
\text { identification } \\
\text { (RFID) } \\
\text { transponders } \\
\text { surgically } \\
\text { implanted beneath } \\
\text { the skin of an } \\
\text { employee is a } \\
\text { more secure } \\
\text { technology for } \\
\text { instituting } \\
\text { employee } \\
\text { identification in } \\
\text { your organisation? }\end{array}$} & \multirow[t]{4}{*}{ Yes } & Count & 9 & 11 & 15 & 46 \\
\hline & & Expected & 19.8 & 20.9 & 20.4 & 19.8 \\
\hline & & $\begin{array}{l}\text { \% within } \\
\text { Q55 }\end{array}$ & $11.1 \%$ & $13.6 \%$ & $18.5 \%$ & $56.8 \%$ \\
\hline & & $\begin{array}{l}\text { Adjusted } \\
\text { Residual }\end{array}$ & -3.1 & -2.8 & -1.5 & 7.5 \\
\hline & \multirow[t]{4}{*}{ No } & Count & 102 & 106 & 99 & 65 \\
\hline & & Expected & 91.2 & 96.1 & 93.6 & 91.2 \\
\hline & & $\%$ within & $27.4 \%$ & $28.5 \%$ & $26.6 \%$ & $17.5 \%$ \\
\hline & & $\begin{array}{l}\text { Adjusted } \\
\text { Residual }\end{array}$ & 3.1 & 2.8 & 1.5 & -7.5 \\
\hline
\end{tabular}


Q55 - Do you think radiofrequency identification (RFID) transponders surgically implanted beneath the skin of an employee is a more secure technology for instituting employee identification in your organisation? * GENERATIONS Crosstabulation

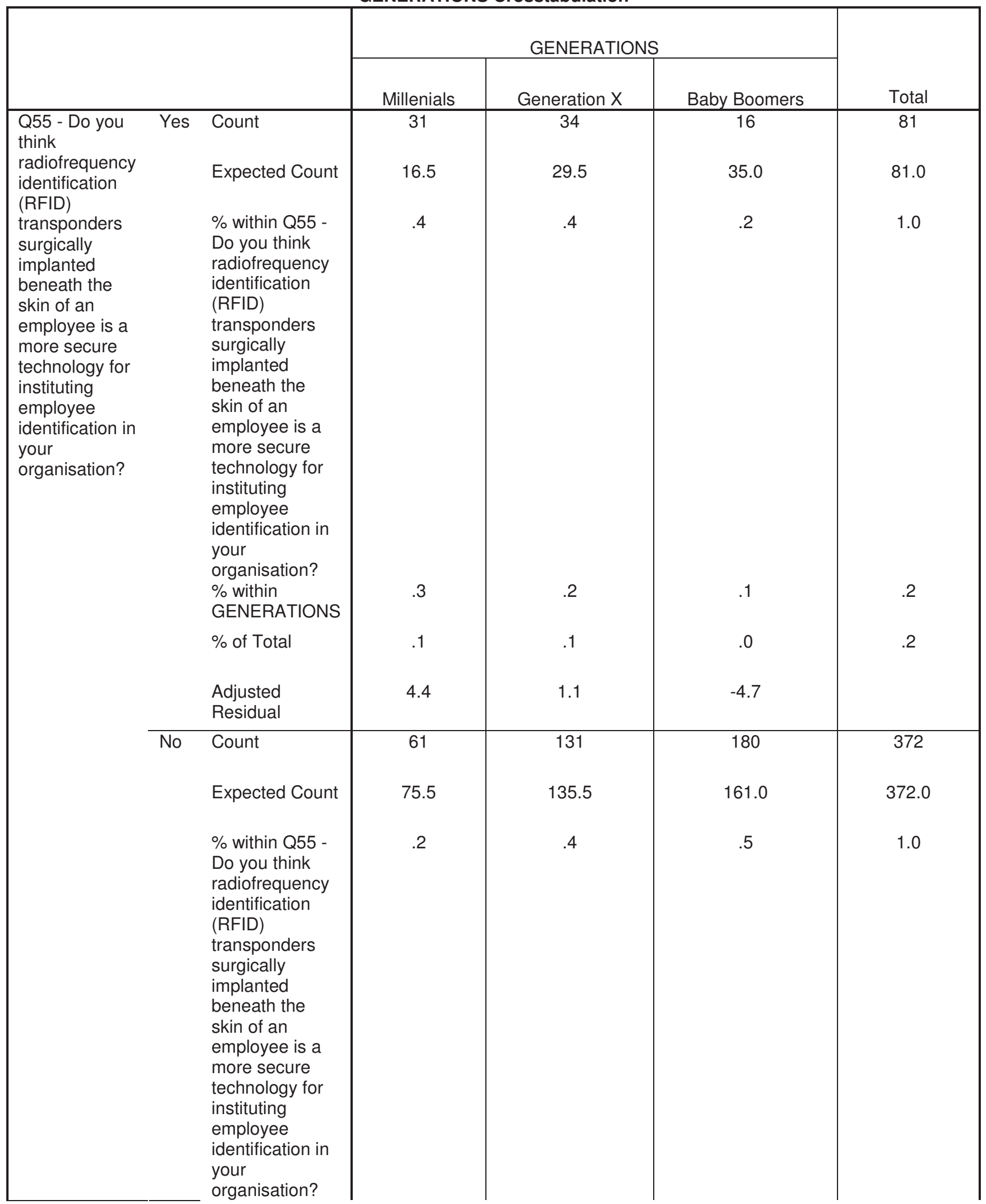




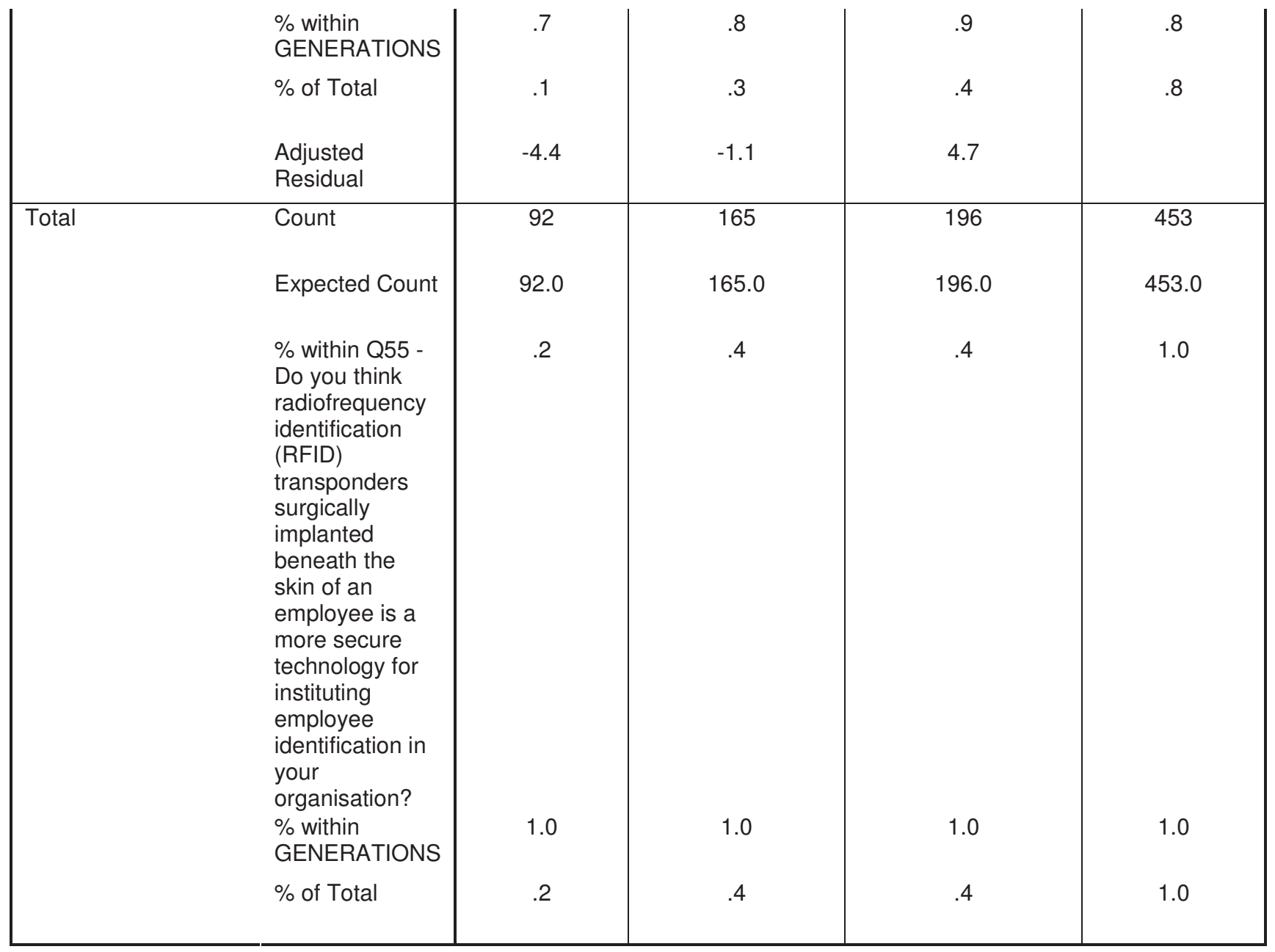

